\title{
Mempersiapkan Generasi Milenial Yang Andal Sebagai Pemimpin Bangsa
}

\author{
Faruq Hasan Asy'ari \\ Universitas Sebelas Maret \\ faruqhasan788@gmail.com
}

\section{Article History}

received $1 / 9 / 2021$

\begin{abstract}
The millennial generation is a generation born between 1980-2000 when there was rapid technological progress and continues to grow. They are called the millennial generation because they are the generation that lives at the turn of the millennium. Simultaneously in today's digital technology began to penetrate into human life rapidly. When viewed from the age, this millennial generation is between 21-41 years old. In this paper, data were obtained from articles and journals, books, and news sources in the mass media. This study uses descriptive analysis method to analyze the data. A leader is someone who is able to move others by commanding, directing, and guiding others, in order to take action in order to achieve an expected goal according to the agreement. With the development of the times, many leaders emerged because of the demands and environmental conditions at this time. Then in the growing era of the millennial generation, the government should have prepared what the millennial generation needs so that they will become ideal leaders for the Indonesian people. In order to be realized, the millennial generation as the regeneration of the nation's leaders must be prepared from an early age by providing nationalism, religion, character and moral education.
\end{abstract}

Keywords: Generation, Millennials, Leadership, Education

\begin{abstract}
Abstrak
Generasi milenial merupakan generasi yang lahir di antara tahun 1980-2000 saat terjadi kemajuan teknologi yang cepat dan terus berkembang. Mereka disebut generasi milenial karena merekalah generasi yang hidup di pergantian milenium. Secara bersamaan di masa sekarang teknologi digital mulai merasuk ke dalam kehidupan manusia dengan pesat. Jika dilihat dari usia, generasi milenial ini berusia diantara 21- 41 tahun. Dalam penulisan ini data didapatkan dari sumber artikel dan jurnal, buku, dan berita yang ada di media massa. Penelitian ini menggunakan metode analisis deskriptif untuk menganalisis data. Pemimpin adalah seseorang yang mampu untuk menggerakkan orang lain dengan memerintah, mengarahkan, dan membimbing orang lain, supaya melakukan tindakan agar tercapai sebuah cita-cita yang diharapkan sesuai kesepakatan. Dengan berkembangnya zaman, banyak pemimpin muncul karena tuntutan dan kondisi lingkungan pada saat ini. Kemudian di masa tumbuhnya generasi milenial sekarang, sudah semestinya pemerintah harus mempersiapkan apa saja yang dibutuhkan generasi milenial agar kelak menjadi pemimpin idaman bagi rakyat Indonesia. Agar terwujud maka generasi milenial sebagai regenerasi pemimpin bangsa harus dipersiapkan sedari dini dengan cara memberikan pendidikan nasionalisme, agama, karakter, dan moral.
\end{abstract}

Kata kunci: Generasi, Milenial, Kepemimpinan, Pendidikan

Social, Humanities, and Education Studies (SHEs): Conference Series https://jurnal.uns.ac.id/shes

p-ISSN 2620-9284

e-ISSN 2620-9292 


\section{PENDAHULUAN}

Sejarah perjalanan lembaga kepemimpian atau kepresidenan Indonesia memiliki keunikan tersendiri, sebagaimana tiap-tiap bangsa memiliki ciri khas pada sejarah pemimpin mereka masing-masing. Perjalanan sejarah yang dilalui lembaga kepresidenan diwarnai setidaknya tiga atau bahkan empat konstitusi. Peraturan dibawah konstitusi hanya mengatur sebagian kecil dan itu pun letaknya tersebar dalam berbagai jenis maupun tingkatan peraturan. Ini berbeda dengan lembaga legislatif dan lembaga yudikatif yang memiliki undang-undang mengenai susunan dan kedudukan lembaga itu sendiri. Lain daripada itu masalah tokoh dan periodisasi juga memerlukan pencermatan lebih lanjut (Supriadi, 2018:140)

Sejak bergulirnya masa reformasi, dimana demokrasi terbuka begitu lebar dan kebebasan berekspresi menjadi ciri utama era ini. Setidaknya lima orang presiden antara 1998 dan 2019 telah memimpin bangsa ini. Presiden B.J. Habibie, K.H. Abdurrahman Wahid, Megawati Soekarno putri sampai Susilo Bambang Yudhonoyo (SBY), dan Joko Widodo, Indonesia telah mencatat sejumlah kemajuan di bidang ekonomi dan politik. Mereka memimpin di bawah bendera reformasi yang didukung oleh pemerintahan yang dipilih oleh rakyat melalui proses yang demokratis panjang dan begitu melelahkan (Solikin dkk, 2017:91)

Tantangan lebih berat dihadapi pemimpin di era milenial. Sebuah era dimana anggota tim atau organisasi terdiri dari banyak atau didominasi oleh generasi milenial. Untuk mengetahui siapakah generasi milenial diperlukan kajian literatur dari berbagai sumber yang merupakan pendapat beberapa peneliti berdasarkan rentang tahun kelahiran. Istilah milenial pertama kali dicetuskan Strauss dan Howe dalam bukunya yang berjudul Millenials Rising: The Next Great Generation (2000). Mereka menciptakan istilah ini tahun 1987 yaitu ketika anak-anak yang lahir tahun 1982 masuk pra-sekolah. Saat itu media mulai menyebut sebagai kelompok yang terhubung ke millennium baru di saat lulus sma di tahun 2000. Jika didasarkan pada Generation Theory yang dicetuskan oleh Karl Manheimmaka generasi milenial adalah generasi yang lahir pada rasio tahun 1980 sampai dengan 2000. Generasi milenial disebut juga sebagai generasi Y. Istilah ini mulai dikenal dan digunakan pada editorial Koran besar Amerika Serikat pada agustus 1993 (Pohan, 2019:157)

Dengan demikian generasi milenial akan meneruskan keberlangsungan kepemimpinan di masa yang akan datang. Generasi milenial diharapkan dapat menjadi agen perubahan yang bergerak dan cepat dalam beradaptasi dengan perubahan zaman. Dengan kata lain pemuda diharapkan menjadi pemimpin masa depan yang lebih baik dari pemimpin masa kini. Maka untuk memiliki pemimpin yang lebih baik perlu dipersiapkan sejak dini.

\section{METODE}

Data didapatkan dengan melakukan studi kepustakaan (library research) dengan menghimpun dan menganalisis dokumen-dokumen, artikel, jurnal, buku penelitian yang telah dilakukan berkaitan dengan mempersiapkan generasi milenial yang andal sebagai pemimpin. Penelitian ini menggunakan metode analisis deskriptif untuk menganalisis data (Sugiyono, 2014). Data ditinjau dan diselidiki dalam tiga tahap; umum, eksploratif, dan fokus belajar. Ini merupakan bahan yang komprehensif dalam upaya meringkas temuan dan menyimpulkan hasilnya. Data dideskripsikan kemudian dianalisis dengan mengacu pada teori yang digunakan sehingga didapatkan gambaran atas fokus penelitian.

\section{Pengertian Generasi Milenial}

\section{HASIL DAN PEMBAHASAN}

Generasi Millenial adalah terminologi generasi yang saat ini banyak diperbincangkan oleh banyak kalangan di dunia berbagai bidang. Millenials atau juga 
dikenal sebagai Generasi Millenial atau Generasi $Y$ adalah kelompok demografis (cohort) setelah Generasi X. Peneliti sosial sering mengelompokkan generasi yang lahir diantara tahun 1980-an sampai 2000-an sebagai generasi millenial. Dapat dikatakan bahwa generasi millenial merupakan generasi muda masa kini yang saat ini berusia dalam rentang usia 21 sampai dengan 41 tahun (Naldo dan Hardika, 2018:36)

Kemudian menurut teori generasi ada 5 generasi yang lahir setelah perang dunia kedua dan berhubungan dengan masa kini, yaitu:

a. Baby Boomer (1946 - 1964) Generasi yang lahir setelah Perang Dunia II ini memiliki banyak saudara, akibat dari banyaknya pasangan yang berani untuk mempunyai banyak keturunan. Generasi yang adaptif, mudah menerima dan menyesuaikan diri. Dianggap sebagai orang lama yang mempunyai pengalaman hidup.

b. Generasi X (1965-1980) Tahun-tahun ketika generasi ini lahir merupakan awal dari penggunaan PC (personal computer), video games, tv kabel, dan internet. Penyimpanan datanya pun menggunakan floopy disk atau disket. MTV dan video games sangat digemari masa ini. Menurut hasil penelitian yang dilakukan oleh Jane Deverson, sebagian dari generasi ini memiliki tingkah laku negatif seperti tidak hormat pada orang tua, mulai mengenal musik punk, dan mencoba menggunakan ganja.

c. Generasi Y (1981-1994) Dikenal dengan sebutan generasi millenial atau milenium. Ungkapan generasi $Y$ mulai dipakai pada editorial koran besar Amerika Serikat pada Agustus 1993. Generasi ini banyak menggunakan teknologi komunikasi instan seperti email, SMS, instan messaging dan media sosial seperti facebook dan twitter. Mereka juga suka main game online.

d. Generasi Z (1995-2010) Disebut juga I Generation, generasi net atau generasi internet. Mereka memiliki kesamaan dengan generasi $\mathrm{Y}$, tapi mereka mampu mengaplikasikan semua kegiatan dalam satu waktu seperti ngetweet menggunakan ponsel, browsing dengan PC, dan mendengarkan musik menggunakan headset. apa pun yang dilakukan kebanyakan berhubungan dengan dunia maya. Sejak kecil mereka sudah mengenal teknologi dan akrab dengan gadget canggih yang secara tidak langsung berpengaruh terhadap kepribadian mereka.

e. Generasi Alpha (2011-2025) Generasi yang lahir sesudah generasi Z, lahir dari generasi X akhir dan Y. Generasi yang sangat terdidik karena masuk sekolah lebih awal dan banyak belajar, rata-rata memiliki orang tua yang kaya (Bencsik \& Machova, 2016:82)

\section{Pengertian Kepemimpinan}

Para ahli mengartikan kepemimpinan selalu menggunakan kata mempengaruhi, artinya bahwa proses mempengaruhi sangat vital dalam kepemimpinan itu sendiri. Salah satu cara mempengaruhi adalah dengan komunikasi yang baik antara pimpinan dan bawahan. Pemimpin yang efektif pada umumnya memiliki kemampuan untuk melakukan komunikasi yang efektif, sehingga sedikit banyak akan mampu merangsang partisipasi orang-orang yang dipimpinnya. Begitu juga pada era milenial digital diharapkan pemimpin mampu beradaptasi dan menggunakan media digital dalam berkomunikasi (Pohan, 2019:167)

Menurut Stephen P. Robbins, (2003:130) Kepemimpinan adalah kemampuan untuk mempengaruhi suatu kelompok guna mencapai serangkaian tujuan. Sedangkan menurut Solikin dkk (2017:93) Kepemimpinan adalah kemampuan seseorang mempengaruhi dan memotivasi orang lain untuk melakukan sesuatu sesuai tujuan bersama yang meliputi proses mempengaruhi dalam menentukan tujuan organisasi, memotivasi perilaku pengikut untuk mencapai tujuan, mempengaruhi untuk memperbaiki kelompok dan budayanya. 
Selain pendapat para ahli diatas tentu masih terdapat banyak pendapat lagi terkait dengan definisi kepemimpinan itu sendiri. Dari definisi diatas, maka dapat disimpulkan bahwa kepemimpinan adalah kemampuan dan keahlian idividu dalam memimpin sehingga dapat mempengaruhi orang lain dalam hal ini adalah anggotanya untuk melakukan kerjasama agar tercapai tujuan yang telah disepakati bersama.

\section{Pendidikan Wajib Guna Mempersiapkan Generasi Milenial Yang Andal Sebagai Pemimpin Bangsa}

Undang-undang nomor 20 tahun 2003 tentang Sistem Pendidikan Nasional, menjelaskan bahwa pendidikan adalah usaha sadar dan terencana untuk mewujudkan sarana belajar dan proses pembelajaran agar perserta didik secara aktif mengembangkan potensi dirinya untuk memiliki kekuatan spiritual keagamaan, pengendalian diri, kepribadian, kecerdasan, akhlak mulia, serta ketrampilan yang diperlukan dirinya, masyarakat, Bangsa dan Negara. Adapun pendidikan yang wajib diberikan kepada generasi milenial yang andal sebagai pemimpin bangsa sebagai berikut:

a. Pendidikan Nasionalisme

Secara etimologis kata Nasionalisme, akar kata dari nation yang berarti bangsa dan isme adalah paham, kalau digabungkan arti dari Nasionalisme adalah paham cinta bangsa (tanah air). Kata nation itu sendiri berasal dari kata nascie yang berarti dilahirkan. Jadi nation adalah bangsa yang dipersatukan karena kelahiran. Sedangkan secara antropologis dan sosiologis, bangsa adalah suatu persekutuan hidup yang berdiri sendiri dan masing-masing anggota persekutuan hidup tersebut merasa satu kesatuan ras, bahasa, agama, sejarah dan adat-istiadat (Yatim, 1999:57). Generasi milenial Indonesia wajib diajarkan sikap nasionalisme dengan cara memberikan pendidikan tentang nasionalisme. Karena merekalah kelak yang akan membawa bangsa ke depan. Melihat sejarah tentang bagaimana nasionalisme terbentuk di Indonesia maka generasi muda akan mendapatkan sebuah gambaran dan akan mengetahui maksud dari terbentuknya nasionalisme Indonesia.

Nasionalisme di Indonesia, terbentuk atas dasar keberagaman seperti yang tercantum dalam dasar negara "Bhineka Tunggal Ika". Jika landasan tersebut runtuh maka tidak dapat dipungkiri akan menjadi resep utama dari kehancuran Indonesia. Uniknya penanaman nilai nasionalisme di Indonesia tidak terlepas dari keadaan keberagaman etnis dan budayanya yang sangat beragam. Sehingga nilai-nilai pluralism dan toleransi harus dijadikan landasan dasar dalam penyusunan pembelajaran multikultural di Indonesia. Dewasa ini, penekanan, pluralism dan kerukunan juga diperlukan berhubung permasalahan radikalisme juga telah mulai merobek persatuan dan kesatuan bangsa. Sentiment negatif berbasis agama telah mulai merasuk kedalam masyarakat yang telah lama mengalami distorsi sectoral yang bermula dari generalisasi sosial dalam masyarakat (Prakasih dkk, 2021:301).

Nasionalisme tidak hanya menjadi semangat yang membuat bangsa Indonesia mampu berjuang mencapai dan mempertahankan kemerdekaannya dari bangsa lain. Lebih dari itu, nasionalisme telah menjadi perekat bangsa ini di saat sejumlah upaya merusak persatuan bangsa datang dari dalam bagian bangsa ini sendiri. Nasionalisme pada saat seperti itu telah menjadi penyelamat bangsa dan negara ini dari perpecahan berlatar belakang agama, etnis, maupun politik yang benihnya akan mudah dipupuk dalam bangsa multikultur seperti Indonesia saat ini. Semangat hidup bersama dalam satu wadah kebangsaan telah menjadikan keinginan sebagian kecil masyarakat untuk memisahkan diri dari keluarga besar bangsa seolah menjadi riak yang tidak berarti. Nasionalisme bahkan menjadi kompromi bersama untuk menjaga keutuhan bangsa dan 
melupakan, namun tanpa meniadakan. perbedaan yang ada. Nasionalisme sejatinya juga dapat menjadi senjata ampuh dalam konteks kehidupan modern terutama di tengah arus globalisasi, terutama untuk mempertahankan identitas bangsa dari gempuran budaya asing. Nasionalisme dapat berfungsi untuk memberikan garis yang jelas antara budaya bangsa yang sesuai dengan perikehidupan masyarakat Indonesia dan budaya asing yang mengurangi rasa kebangsaan secara nasional. Nasionalisme dengan demikian diharapkan menjadi filter aktif yang membentengi bangsa dari gaya hidup ala bangsa lain yang tidak sesuai bahkan tidak konstruktif bagi pembangunan karakter bangsa Indoensia (Hamid, 2012:3).

Penanaman jiwa nasionalisme perlu dilakukan di lembaga pendidikan, hal ini dikarenakan bahwa lembaga pendidikan merupakan tempat pendidikan dan pembentukan jiwa serta semangat bagi generasi muda yang akan menentukan masa depan bangsa Indonesia di masa yang akan datang. Selain itu, sejumlah besar generasi muda penerus bangsa Indonesia masih berstatus sebagai pelajar, dengan demikan apabila lembaga pedidikan mampu memberikan pendidikan nasionalisme penguatan karakter bangsa Indonesia maka akan selamatlah di masa yang akan datang. Penanaman jiwa nasionalisme serta penguatan karakter bangsa bagi seluruh pelajar dan mahasiswa di Indonesia akan memperkokoh persatuan dan kesatuan bangsa dalam rangka mewujudkan $\mathrm{NKRI}$ yang kuat dan kokoh serta berkepribadian. Dalam rangka membentuk dan menumbuhkan rasa nasionalisme serta karakter bangsa bagi pelajar dan mahasiswa diperlukan suatu sarana yang dapat melengkapi penyelenggaraan pendidikan di sekolah. Sajian informasi berupa materi yang menarik dan relevan dengan semangat kemudahan pelajar dan mahasiswa, perlu dikembangkan dengan tepat (Widiyono, 2019:18).

b. Pendidikan Agama

Berbicara masalah Agama sudah tentu membicarakan tentang kepercayaan, keyakinan dan akidah yang dianut oleh manusia sebagai pandangan hidupnya. Tidak dapat dipungkiri bahwa dalam kehidupan manusia ada norma-norma atau aturan-aturan dan undang-undang yang sifatnya mengikat dan mengatur manusia itu sendiri supaya ia tidak terombang-ambing dalam mengisi kehidupannya sehari-hari. Disamping itu adanya norma-norma sosial masyarakat yang mengatur hubungan antara sesama manusia dan normanorma yang mengatur hubungan antara khalik dengan makhluk-Nya. Pada prinsipnya telah nyata bahwa manusia menurut fitrahnya cenderung untuk beragama (mempercayai adanya tuhan), baik dengan dasar keyakinan yang betul tertanam dalam lubuk hati seseorang itu tanpa was-was (Nurmayani, 2013:69).

Konsep pendidikan agama dapat diartikan aturan atau isi ajaran agama yang tersusun dengan rapi. Isi ajaran agama ini dikemas dengan baik secara sistematis, terstruktur dan komprehensif. Pendidikan agama yang termuat dalam konsep atau formal belajar dapat diakses semua orang. Lembaga pendidikan, melalui pendidik yang profesional dan berdedikasi tinggi akan mampu mengarahkan peserta didik menjadi pribadi baik. Secara khusus, pendidik yang mengajarkan pendidikan agama dengan profesional akan menguatkan pemahaman peserta didik. Pemahaman agama menjadi bekal bagi peserta didik dalam menjalani aktifitas sehari-hari. Karena pada dasarnya peserta didik adalah generasi milenial yang masih membutuhkan pendidikan. Substansi pendidikan adalah memanusiakan manusia, menempatkan kemanusiaan pada derajat tertinggi dengan memaksimalkan karya dan karsa. Pendidikan adalah utama, suatu ketentuan yang sudah mengikat baik secara sukarela atau terpaksa. 
Artinya, generasi milenial dijamin haknya mendapatkan akses pendidikan di dalam sistem pemerintahan Indonesia (Sulthani, 2020:223)

Maka dapat dimengerti bahwa pendidikan agama diperlukan dalam pembentukan akhlak generasi milenial yang memanusiakan masnusia, karena tujuan pendidikan agama untuk membentuk pribadi yang berakhlak mulia sehingga ketika sudah menjadi pemimpin akan dihormati karena memiliki kepribadian yang baik dan menjadi teladan. Selain itu dengan pendidikan agama pemimpin bangsa Indonesia tidak mudah terpengaruh hal negatif seperti; korupsi, kolusi, dan nepotisme yang sudah mendarah daging di pemerintahan Indonesia.

c. Pendidikan Karakter

Karakter adalah lukisan jiwa yang termanifestasi dalam perilaku. Karakter dalam Kamus Besar Bahasa Indonesia diartikan dengan "tabiat, sifat-sifat kejiwaan, akhlak atau budi pekerti yang membedakan seseorang dengan yang lain, dan watak.

Pendidikan karakter adalah pendidikan yang menyeimbangkan ilmu pengetahuan (iptek) dengan ilmu agama (imtak), sehingga Individu memiliki kesadaran untuk berbuat yang terbaik atau unggul, dan mampu bertindak sesuai potensi dan kesadarannya tersebut. Pendidikan berbasis karakter merupakan sebuah pembelajaran yang sangat perlu dilakukan untuk memperbaiki kualitas moral generasi milenila. Karakter merupakan jati diri seseorang yang menentukan sikap dan perilaku seseorang di masyarakat. Pendidikan berbasis karakter merupakan cara untuk membuat seseorang mengerti, memahami dan bertindak sesuai dengan etika dan norma yang berlaku. Pendidikan berbasis karakter telah menjadi agenda nasional saat ini. Sesuai dengan peraturan yang dikeluarkan presiden tentang Penguatan Pendidikan Karakter yang tertuang dalam Perpres No. 87 Tahun 2017, bahwa arahan ini sebagai dasar dari revolusi mental yang menjadi salah satu tujuan pemerintah melalui sektor pendidikan (Rafid, 2018:716).

Karakter bangsa Indonesia adalah karakter yang dimiliki warga negara Indonesia berupa tindakan-tindakan yang dinilai sebagai suatu kebajikan berdasarkan nilai yang berlaku di Indonesia. Oleh karena itu, pendidikan karakter bangsa diarahkan pada upaya mengembangkan nilai-nilai yang mendasari suatu kebajikan sehingga menjadi sebuah solusi untuk meningkatkan mutu pendidikan. Pendidikan karakter yang berhasil diterapkan akan menghasilkan nilai religius, jujur, toleransi, displin, kerja keras, kratif, mandiri, demokrasi, rasa ingin tahu, semangat kebangsaan, cinta tanah air, menghargai prestasi, bersahabat dan komunikasi, cinta damai, gemar membaca, peduli lingkungan, peduli sosial serta bertanggung jawab (Fitriyani, 2018: 309).

Dengan demikian harapannya generasi millenial dengan diberikannya pendidikan karakter diharapkan dapat mengembangkan potensi kalbu atau nurani sebagai manusia dan warga negara yang memiliki nilai-nilai budaya bangsa. Dapat mengembangkan kebiasaan dan perilaku yang terpuji sejalan dengan tradisi dan budaya bangsa Indonesia. Menanamkan sikap siap sebagai generasi milenial yang akan meneruskan kepemimpian di Indonesia.

d. Pendidikan Moral

Moral berasal dari kata latin mores, yang berarti tata cara, kebiasaan, dan adat. Perilaku moral dikendalikan konsep-konsep moral - peraturan perilaku yang telah menjadi kebiasaan bagi anggota suatu budaya dan yang menentukan pola perilaku yang diharapkan dari seluruh anggota kelompok. Istilah moral sendiri dapat diartikan sebagai ukuran-ukuran yang menentukan benar atau salah atau baik buruk yang berlaku di masyarakat secara luas (Adhe, 2016:44). Kemudian pengertian pendidikan moral adalah kesadaran untuk membantu 
peserta didik melalui ilmu pengetahuan, keterampilan-keterampilan, sikap, dan nilai yang memberikan kontribusi pada kepuasan individu dan kehidupan sosial. Definisi ini menggambarkan bahwa pendidikan moral bermuara pada dua tujuan. Pertama, membantu generasi muda dalam memperoleh ilmu pengetahuan, keterampilan, sikap, dan nilai untuk kepuasaan hidup yang lebih baik. Kedua, membantu individu mencapai kehidupan sosial sekaligus memberikan kontribusi kepada terciptanya masyarakat yang lebih baik didasarkan pada kepedulian dan perasaan kasih kepada umat manusia dan makhluk hidup serta tidak mengganggu hak-hak orang lain untuk memenuhi nilai legitimasi dirinya (Kirschenbaum, 1995:41).

Pada dasarnya pendidikan moral bertujuan sangat mulia yaitu untuk membentuk generasi milenial sebagai individu yang berkualitas, memiliki rasa kemanusiaan, rasa demi persatuan menjunjung tinggi nilai-nilai gotong royong. Salah satu hal yang sangat memprihatinkan di kalangan generasi milenial adalah adanya kualitas moral. Semakin melunturnya norma dan nilai-nilai agama dan susila dalam masyarakat, berubahnya persepsi dan kebiasaan tatanan kehidupan membawa kontribusi yang luar biasa bagi penurunan kualitas moral. Bahkan dalam sebagian generasi muda cenderung untuk melawan nilai dan arus dalam masyarakat yang ada. Menyiapkan generasi milenial untuk mampu menyelesaikan berbagai persoalan bangsa serta menjauhkan mereka dari kontaminasi berbagai virus yang menggerogoti mentalitas bangsa dan hal-hal negatif dari generasi milenial. Untuk memfilter berbagai pengaruh negatif globalisasi, dalam pendidikan perlu dikembangkan konsep dan implementasikan yang didasarkan pada moral. Pendidikan moral harus mewarnai segala instrument pendidikan dalam rangka menyiapkan generasi milenial menjadi regenerasi pemimpin bangsa seperti yang diharapkan rakyat Indonesia.

\section{SIMPULAN}

Generasi Millenial adalah terminologi generasi yang saat ini banyak diperbincangkan oleh banyak kalangan di dunia berbagai bidang. Millenials atau juga dikenal sebagai Generasi Millenial atau Generasi $Y$ adalah kelompok demografis (cohort) setelah Generasi X. Generasi milenial merupakan regenari pemimpin bangsa yang akan datang. Kepemimpinan adalah kemampuan dan keahlian idividu dalam memimpin sehingga dapat mempengaruhi orang lain dalam hal ini adalah anggotanya untuk melakukan kerjasama agar tercapai tujuan yang telah disepakati bersama.

Pendidikan wajib guna mempersiapkan generasi milenial yang andal sebagai pemimpin bangsa. Adapun pendidikan yang wajib diberikan kepada generasi milenial yang andal sebagai pemimpin bangsa sebagai berikut; 1. Pendidikan Nasionalisme yaitu mempelajari paham cinta bangsa (tanah air), 2. Pendidikan Agama yaitu mempelajari tentang kepercayaan, keyakinan dan akidah yang dianut oleh manusia sebagai pandangan hidupnya, 3. Pendidikan karakter yaitu mempelajari tentang lukisan jiwa yang termanifestasi dalam perilaku, dan 4. Pendidikan moral yaitu mempelajari kesadaran untuk membantu peserta didik melalui ilmu pengetahuan, keterampilan-keterampilan, sikap, dan nilai yang memberikan kontribusi pada kepuasan individu dan kehidupan sosial

\section{DAFTAR PUSTAKA}

Adhe, Kartika Rinakit. 2016. Guru Pembentuk Anak Berkualitas. Jurnal CARE Edisi Khusus Temu IImiah, Vol. 03 (3) (42-51).

Bencsik, A., \& Machova, R. 2016. Knowledge Sharing Problems from the Viewpoint of Intergeneration Management. In ICMLG2016 - 4th International Conferenceon Management, Leadership and Governance: ICMLG2016 (p.42). Academic Conferences andpublishing limited. 
Fitriyani, Pipit. 2018. Pendidikan Karakter Bagi Generasi Z. Prosiding Konferensi Nasional Ke- 7. Asosiasi Program Pascasarjana Perguruan Tinggi Muhammadiyah, Aisyiyah (APPPTMA) (307-314).

Hamid, Edy Suandi. 2012. Peran Pendidikan untuk Mengukuhkan Nasionalisme dan Membangun Karakter Bangsa. Jurnal UNISIA, Vol. 34 (76) (1-8).

Kirschenbaum, H. 1995. 100 Ways to Enhance Values and Morality in Schools and Youth Settings. Boston: Allyn and Bacon.

Naldo dan Hardika Widi Satria. 2018. Studi Observasi terhadap Penggunaan Aplikasi LINE oleh Generasi Millenial. Jurnal Sosial Humaniora Terapan. Vol 1 (1) (32-40)

Nurmayani. 2013. Pentingnya Pendidikan Agama Bagi Remaja. Jurnal Pengabdian Kepada Masyarakat, Vol. 19 (74) (69-78).

Pohan, Hasril Atieq. 2019. Kepemimpinan Di Era Milenial Ditinjau dari Aspek Komunikasi. Jurnal Komunikasi Islam dan Kehumasan (JKPI), Vol. 3 (2) (156174).

Prakasih Raga Cipta, Firman, dan Rusdinal. 2021. Nilai Nasionalisme Dan Anti Radikalisme Dalam Pendidikan Multikultural. Jurnal Pendidikan Indonesia, Vol. 2 (2) (294-302).

Rafid, R. 2018. Konsep Kepribadian Muslim Muhammad lqbal Perspektif Pendidikan Islam Sebagai Upaya Pengembangan Dan Penguatan Karakter Generasi Milenial. Mitra Pendidikan, 2(7), 711-718.

Solikin, Asep, Fatchurahman dan Supardi. 2017. Pemimpin Yang Melayani Dalam Membangun Bangsa Yang Mandiri. Anterior Jurnal, Vol 16 (2) (90-103).

Stephen P. Robbins. 2003. Essentials of Organization Behavior ( $7^{\text {th }}$ ed). (New Jersey: Pearson Education, Inc.

Sugiyono. 2014. Metode Penelitian Pendidikan Pendekatan Kuantitatif, Kualitatif, dan $R \& D$. Bandung: Alfabeta.

Sulthani, Dinil Abrar. 2020. Konsep Pendidikan Agama Pada Zaman Milenial. Indonesian Journal of Islamic Education Studies (IJIES), Vol 3, (2), (216-235).

Supriadi, Hasan. 2018. Gayakepemimpinanpresidenindonesia. Jurnal Agregasi, Vol .6 (2) (139-148).

Widiyono. 2019. Pengembangan Nasionalisme Generasi Muda di Era Globalisasi. Jurnal Populika, Vol 7 (1) (12-21).

Yatim, Badri. 1999. Soekarno Islam dan Nasionalisme. Jakarta: PT. Logos Wacana IImu. 